\title{
Health Education - Health Misconceptions - Teacher Training Lessons Learnt from a Hungarian Pilot Study
}

\author{
Zoé Mónika Lipták \\ University of Szeged, Hungary \\ Klára Tarkó \\ University of Szeged, Juhász Gyula \\ Faculty of Education, Hungary
}

\section{Abstract}

A major goal of schools is to provide students with knowledge and skills applicable (Csapó, 1998). However, teachers have to deal with the misconceptions of their students described as ideas based on experience leading to faulty understanding or naïve ideas (Martin et al., 2002). Schools are of primary importance in transmitting health-related knowledge, skills, attitudes and responsibilities, and health education provided by teachers is key in fighting against the health misconceptions students bring from their immediate environment and those transmitted by the Media. The aim of the present study was to pilot the research questionnaire designed to measure the health misconceptions of teacher trainees. The pilot sample contained 68 students. The research tool was an anonymous, self-administered questionnaire (Chronbach's Alpha: 0.878) containing open-ended questions referring to the participants' understanding of health, as well as multiplechoice questions on health misconceptions, together with background sociodemographic questions. From among the holistic dimensions of health (physical, mental, emotional, spiritual, societal, social) the physical dimension dominated the health concept of the respondents (95.2\%). Looking at the sample mean, they correctly assessed that lifestyle (43\%) plays the most important role in the development of their health. From among the 37 presented health statements, misconceptions could be detected in case of 23 statements (62\%). The source of their existing misconceptions about health was the Media and family members. Our research intends to show which areas of health should be addressed more among future educators and thus indirectly among students, which misconceptions are worth clarifying at the outset.

Keywords: Health, misconceptions, holistic health dimension, education 


\section{Introduction}

The issue of children's cognition has been investigated for several decades. As a result of changes in pedagogy and psychology, scientists have begun to address misconceptions. The most important such change in the field of pedagogy is to provide students with knowledge and skills applicable in everyday life (Csapó, 1998). International studies revealed that people's misconceptions about health affect what therapy they accept for a particular disease, what medical services they draw on, and what lifestyle they follow. In addition, the knowledge people transfer to one another has a major impact on the aforementioned (Leventhal, Leventhal \& Robitaille, 1998; Moorman \& Matulich, 1993). All these indicate that the existence of misconceptions about health is an influencing factor that we have to deal with, especially since we are not aware of any such studies in Hungary.

The concept of misconception varies widely, indicating the lack of correct scientific facts. It can be based on superstition, myth, folk traditions, or misunderstandings. It may stem from misinterpretation or a lack of thorough observation of the facts, but may also reflect a mere lack of information. (Wilfred \& Sutton, 1962). Concepts are ideas, facts, or events that help to understand the world around us (Eggen \& Kauchak, 2004). However, misconceptions can be described as ideas that are based on experience and lead to misconceptions. (Martin et al., 2002). 'Misconceptions is an inaccurate notion of concepts, the use of false concepts, the classification of false examples, the confusion of different concepts and the hierarchical relationships of incorrect concepts' (Saputra et al., 2019, p. 1). Health misconceptions are 'distorted or false ideas about health matters' (Bedworth \& Bedworth, 2010, p. 238).

The researchers noticed similarities between the erroneous responses of each student, most of which are not random, and we can even use a categorization along the types of erroneous ideas. In addition, consistency can be observed for the erroneous responses. All these lead to the conclusion that there are erroneous parts in pupils' conceptual network arranged in the same way (Korom, 1997). Naive ideas are stable, not easy to change, profound, and can make learning difficult. The age, gender, school performance and skills of the child do not or just slightly affect their development. It is difficult to map their presence, as in multiple choice tests children have to give account on their learning based on a pattern (Korom, 2002).

Health is a scientific category as well as an everyday concept. The scientific evolution brought to life a paradigm change in the health concept, and the one-dimensional, pathogenic, objective, organic, individual and static understanding was replaced by a salutogenic, positive, multidimensional, subjective, personal, situation-based and dynamic approach (Benkő, 2011). It is positive because instead of a lack of illnesses, it focuses on the physical, mental, social, spiritual and ecological well-being (WHO, 1948). Highlighting the aforementioned factors already indicates that there is more to it than just physical health; the multidimensional approach is summarized even 
more vividly by the holistic concept of health, with its physical, mental, emotional, spiritual, social and societal dimensions (Naidoo \& Wills, 1999; Benkő, 2019).

The aim of our research is to explore the health concept of future teachers, to reveal the existence of health misconceptions and their types. There have been several Hungarian researches into the misconceptions of pupils, but none of them focused on health misconceptions. By exploring the health misconceptions of future teachers, identifying the reasons behind and formulating intervention points and methods, the health education activities of public education institutions can become more effective.

\section{Methodology}

The applied online questionnaire was created with the help of Google Questionnaire Builder, and its link was shared in community platforms. The preliminary condition of participating in the research was being a Hungarian higher education student, studying preferably in teacher training. To our call 68 higher education students replied during the given two-weeks period, and there were students studying not only education but sociology and health sciences also among the participants. There were only $5(7.4 \%)$ men among the respondents. The mean age of respondents was 27.9 (SD: 7.93) years.

Our questionnaire was completed voluntarily and anonymously. The questions were created based on a thorough literature study. In the first open-ended question we have explored the health concept of respondents. Our second open-ended question studied the weight of factors defining health, expressed in percentages. Our third question measuring participants' health misconceptions consisted of 40 health statements to be evaluated on a 5-points Likert scale, together with an open-ended question asking about the information sources they based their answers on. Finally, we put forward open-ended and closed questions asking about the sociodemographic background of the respondents.

According to our first hypothesis, the health concept of future educators does not reflect the complexity of the modern, holistic understanding of health; regardless of age, sex, family background, and specialization, the predominance of the physical health dimension can be observed. In our second hypothesis, we presupposed that the health misconceptions of future educators are undergoing a continuous transformation, depending on age, sex, family background, type of higher education institution, and specialization. The transformation can be grasped in the complexity and orientation of misconceptions, according to which misconceptions can be organized into categories. Finally, according to our third hypothesis, the health concept and health misconceptions of future educators are shaped by lay (parents, friends, acquaintances, etc.) and popular (media, social media) information sources, and their formal training (public education, higher education) is of weak efficiency. 


\section{Results}

\subsection{The study of the health concept}

To reveal respondents' perceptions of health, we used the following question: What image comes to your mind first when you hear the word health? Tell us what you see in the picture and write a short explanation!

The answers to the open-ended question were categorized based on the six dimensions of the holistic health concept. The results clearly pointed in the direction of our first hypothesis, namely that respondents' health perceptions were characterized by the predominance of the physical health dimension (95.2\%).

Since Lalonde (1974) Canadian health minister's research it is widely known that lifestyle $(43.0 \%)$ plays the most important role in our health. To examine how our respondents perceive this connection, we put forward the following question: You have a total of 100 health points that you need to divide into the following 4 factors according to the extent they may affect your health. How many points would you give them? You have to distribute all 100 points!

We obtained the same proportions as Lalonde reported, meaning our respondents saw the importance of lifestyle correctly. However, further analysis is needed concerning who has attributed the strongest influence to lifestyle and what health concepts they have. Thus, we will be able to conclude which health factors future educators find important in the shaping of lifestyle. With the above question and analysis, we wanted to examine our first hypothesis also. If the predominance of the physical health dimension is confirmed in our large-sample research, we suggest considering the separation of school health promotion from physical education and its re-introduction as an independent subject in Hungary, since as a consequence everyone identifies health with physical health only, which is a very important element, but only one of the six holistic health dimensions.

\subsection{Health-related statements}

Based on a literature study we have explored those health statements the answers to which reflect the most common misconceptions. The degree of agreement with each statement was measured on a five-point Likert scale ranging from 'not true at all' to 'perfectly true'. We have examined the holistic health variables by demographic variables also, however there was only one significant case (this might primarily be attributable to the low sample size) and the latter is also questionable, as only six respondents have mentioned spiritual health (Table 1.). We examined the relationship between the six dimensions of holistic health and each health statement. The holistic health dimension variables were nominal, where 0 meant it did not, 1 meant it did appear in the health definition of respondents; the health statements were ordinal variables. Thus, if the Spearman's correlation coefficient was positive, it meant agreement with a statement, while when it was negative it meant 
disagreement with a statement. Those indicating the physical health dimension in their health definitions agreed to a greater extent with the following health statements: 'lice love the untidy, dirty hair'; 'if you eat a lot of carrots your eyesight will be better'; 'stress causes high blood pressure'. In contrast, they were less likely to agree with the health statement: 'there are genetic causes behind obesity'.

Table 1. Relationships between the demographic variables and our holistic health variables

\begin{tabular}{|c|c|c|c|c|}
\hline $\begin{array}{c}\text { Demographic } \\
\text { variables }\end{array}$ & Holistic health & Chi-square & $\mathrm{df}$ & Sig. \\
\hline \multirow{6}{*}{ grade } & physical health & 3.029 & 4 & 0.553 \\
\hline & mental health & 2.756 & 4 & 0.599 \\
\hline & emotional health & 6.730 & 4 & 0.151 \\
\hline & spiritual health & 1.837 & 4 & 0.766 \\
\hline & social health & 2.730 & 4 & 0.604 \\
\hline & societal health & 4.068 & 4 & 0.397 \\
\hline \multirow{6}{*}{ course } & physical health & 4.200 & 9 & 0.898 \\
\hline & mental health & 9.168 & 9 & 0.422 \\
\hline & emotional health & 7.234 & 9 & 0.613 \\
\hline & spiritual health & 9.229 & 9 & 0.416 \\
\hline & social health & 8.183 & 9 & 0.516 \\
\hline & societal health & 5.385 & 9 & 0.799 \\
\hline \multirow{6}{*}{$\begin{array}{l}\text { mother's highest } \\
\text { level of education }\end{array}$} & physical health & 7.948 & 6 & 0.242 \\
\hline & mental health & 8.477 & 6 & 0.205 \\
\hline & emotional health & 6.773 & 6 & 0.342 \\
\hline & spiritual health & 16.601 & 6 & 0.011 \\
\hline & social health & 12.198 & 6 & 0.058 \\
\hline & societal health & 5.985 & 6 & 0.425 \\
\hline \multirow{6}{*}{$\begin{array}{l}\text { father's highest } \\
\text { level of education }\end{array}$} & physical health & 3.423 & 6 & 0.754 \\
\hline & mental health & 1.343 & 6 & 0.969 \\
\hline & emotional health & 0.984 & 6 & 0.986 \\
\hline & spiritual health & 3.781 & 6 & 0.706 \\
\hline & social health & 3.834 & 6 & 0.699 \\
\hline & societal health & 5.285 & 6 & 0.508 \\
\hline \multirow{6}{*}{ settlement type } & physical health & 1.099 & 3 & 0.777 \\
\hline & mental health & 2.068 & 3 & 0.559 \\
\hline & emotional health & 1.847 & 3 & 0.605 \\
\hline & spiritual health & 1.391 & 3 & 0.708 \\
\hline & social health & 2.859 & 3 & 0.414 \\
\hline & societal health & 4.712 & 3 & 0.194 \\
\hline
\end{tabular}


In six out of the 40 health statements presented in the questionnaire, a significant difference could be found between the two sexes, while in a further seven cases the relationship was trend-like, which means that a significant correlation would probably be proven in case of a larger sample size.

\subsection{The relationship of health statements with age}

The relationship of health statements with age were studied with the help of Spearman's rank correlation coefficient, as the variables involved were ordinal. In the case of health statements showing a significant correlation with age, we saw a negative relationship: the older someone was, the less she or he agreed with the following health statements: 'it is easy to quit smoking'; 'it doesn't matter if I weight more as a child, I will grow it out'; 'milk teeth care is not so important, they fall out anyway'.

\subsection{The relationship of health statements with parents' level of education}

The mother's and the father's level of education were ordinal variables, that is why the Spearman's rank correlation coefficient was used to measure their relationship with all the target variables. There was only one health statement the mother's level of education had a significant negative correlation with ( $r h o=-0,363 ; p=0,003$ ): 'Stress causes high blood pressure'. Meaning, the higher the education level of someone's mother was, the less she or he agreed with this statement. The father's level of education did not significantly correlate with any of the health statement variables. Focusing on the significant correlations we can say, that women were more likely to agree with the following health statements: 'the best antidote of hangover is to drink some alcohol'; 'a lot of stress makes you sick'; 'stress causes high blood pressure'; and 'you should drink eight glasses of water every day'. Compared to women, men agreed more with the following health statements: 'diabetics are not allowed to sport'; and 'smoking is not addictive'.

\section{Conclusions}

Due to the relatively low number of respondents we could not perform an analysis by all background variables. We have found our measuring instrument suitable to study our first and third hypothesis. However, in order to examine our second hypothesis more precisely, we consider it necessary to restructure the listed health statements and to formulate some statements more clearly. We consider it important to examine the topic in order to draw attention to the importance of making health promotion a separate subject in Hungarian public education. Our research intended to show which areas of health should be addressed more among future educators and thus indirectly among students, which misconceptions are worth clarifying at the outset. We would also like to reveal the sources - family, teacher, media, etc. - from which each misconception was obtained, so as to be able to teach future educators how to handle the incoming information. 


\section{References}

[1] D.A. Bedworth and A.E. Bedworth, Dictionary of Health Education. New York: Oxford University Press, 2010.

[2] Zs. Benkő, " Az egészségfejlesztő szakemberek a magyar közoktatásban. A felsőoktatás válasza," Egészségfejlesztés, vol. 52, no. 3, 2011.

[3] Zs. Benkő, "Az egészség történeti és modern megközelítése. Az egészségfejlesztés fogalma, szemléletmódja" In: Az egészség az életünk tartópillére. Egészségtanácsadási kézikönyv (Benkő Zsuzsanna, Lippai László, Tarkó Klára eds.), pp. 15-49., Szeged: JGYTF Kiadó, 2019.

[4] Csapó, "Az iskolai tudás", Budapest: Osiris Kiadó, 1998.

[5] P. Eggen and D. Kauchak, "Educational Psychology: Windows, Classrooms." Upper Saddle River: Pearson Prentice Hall, 2004.

[6] "Hungarian Public Education Act",2011. https://net.jogtar.hu/jogszabaly?docid=A1100204.TV

[7] Korom, "Naiv elméletek és tévképzetek a természettudományos fogalmak tanulásakor," Magyar Pedagógia, vol. 97, no. 1, pp. 19-40, 1997.

[8] Korom, „Az iskolai tudás és a hétköznapi tapasztalat ellentmondásai.” In: $A z$ iskolai tudás (Csapó Benő eds.), pp. 149-175, Budapest: Osiris Kiadó, 2002.

[9] M. Lalonde, A New Perspective on the Health of Canadians. Ottawa, Ontario, Canada: Minister of Supply and Services, Ottawa, 1974.

[10] Leventhal, H. Leventhal, and C. Robitaille, Enhancing self-care research: Exploring the theoretical underpinnings of self-care. In: Self-care in later life, (M. G. Ory and G. H. DeFriese eds.), pp. 118-141, New York: Springer, 1998.

[11] R. Martin, C. Sexton, and J. Gerlovich, Teaching Science for all Children: Methods for Constructing Understanding. Boston: Allyn and Bacon, 2002.

[12] Moorman, and E. Matulich, A model of consumers' preventive health behaviors: The role of health motivation and health ability, Journal of Consumer Research, vol. 20, pp. 208-228, 1993.

[13] J. Naidoo, J. Wills, "Egészségmegőrzés," Budapest: Medicina Kiadó, 1999.

[14] O. Saputra, A. Setiawan, and D. Rusdiana, Identification of student misconception about static fluid. Journal of Physics: Conference Series, vol. 1157, no. 3, pp. 1-6., 2019. https://doi.org/10.1088/1742$6596 / 1157 / 3 / 032069$

[15] J. Sólymosy, "Teljes körű iskolai egészségfejlesztési koncepció," Egészségfejlesztés, vol. LVII, no. 1, pp. 53-54., 2016. 
[16] WHO, Constitution of the World Health Organization. Geneva: World Health Organization. Preamble to the Constitution of WHO as adopted by the International Health Conference, New York, 19 June - 22 July 1946; signed on 22 July 1946 by the representatives of 61 States (Official Records of WHO, no. 2, p. 100) and entered into force on 7 April 1948.

[17] Wilfred and Ed. D. Sutton, "Misconceptions about health among children and youth," School health, vol. 32, no. 9, pp. 347-351, 1962. 